\title{
Geophysical Data Bearing on Hydrocarbon Traps and Resource Potential of the Galisteo Basin, New Mexico
}

\author{
Richard A. Ashu', Michael S. Petronis ${ }^{2}$ \\ ${ }^{1}$ Harold Hamm School of Geology and Geological Engineering, University of North Dakota, Grand Forks, USA \\ ${ }^{2}$ Department of Natural Resources, New Mexico Highlands University, Las Vegas, USA \\ Email: Richardashu2@gmail.com
}

Received December 4, 2013; revised January 3, 2014; accepted January 11, 2014

Copyright (c) 2014 Richard A. Ashu, Michael S. Petronis. This is an open access article distributed under the Creative Commons Attribution License, which permits unrestricted use, distribution, and reproduction in any medium, provided the original work is properly cited. In accordance of the Creative Commons Attribution License all Copyrights (C) 2014 are reserved for SCIRP and the owner of the intellectual property Richard A. Ashu, Michael S. Petronis. All Copyright (C 2014 are guarded by law and by SCIRP as a guardian.

\section{ABSTRACT}

Land-based gravity and magnetic data were obtained at 56 gravity stations and 250 magnetic stations throughout the northern-central part of the Galisteo Basin south of Santa Fe, NM. The study area extends south from the village of Eldorado to the foothills of the Ortiz Mountains and east from I-25 to Highway 285, an area of approximately 2200 square kilometers. These data offered an approach to integrating surface geological mapping and subsurface geophysical surveys to characterize the distribution, depth, and potential hydrocarbon trap geometries in parts of the Galisteo Basin using the Talwani geophysical modeling program. Both sets of potential field data were integrated into ArcGIS and Surfer to generate extrapolated surfaces and derivative maps, which allowed for the characterization of the subsurface geology along with specific profiles across the mapped area. These data revealed several anomalies within the central portion of the basin that are interpreted as likely hydrocarbon trap-structures.

\section{KEYWORDS}

\section{Galisteo Basin; Hydrocarbon Traps; Gravity Survey; Magnetic Survey; Talwani}

\section{Introduction}

The evaluation of trapping mechanisms is a fundamental step in the analysis of prospective sites for resource assessments or successful oil and gas exploration. A trap may be defined as a geometric configuration of rocks suitable for containing hydrocarbons and sealed by a relatively impermeable layer through which hydrocarbons will not migrate. The present work tested the hypothesis that igneous intrusions during a late Tertiary magmatic event and earlier fold and fault of the country rock contributed to the formation of sizable petroleum traps in the Galisteo Basin (Figure 1). In order to test this hypothesis, a geological mapping and geophysical surveying (gravity and magnetic) campaign was conducted to identify the geometry, distribution, and depth of the igneous intrusions and other structures that likely serve as petroleum traps in some locations in the Galisteo Basin. Whether these traps are filled with hydrocarbons is a subject of debate and is not addressed in this research project.

Potential field data were obtained using a gravimeter and a proton magnetometer to constrain the basin architecture. Merging field mapping information and potential field data from gravity and magnetic surveys provided a means to assess the petroleum potential of the GalisteoBasin, and characterize the numerous igneous intrusions of various geometries that intrude the basin. The data were modeled using the Talwani-forward modeling program [1]. Models were created along with different profiles that characterize the deep basin geometry, likely locations of structural traps, the relative positions of the basin sediments, and intrusions at depth.

The Galisteo Basin presents exploration challenges associated with its complex structural architecture and an overall poor understanding of its hydrocarbon systems. The geology includes a wide variety of rock types including 


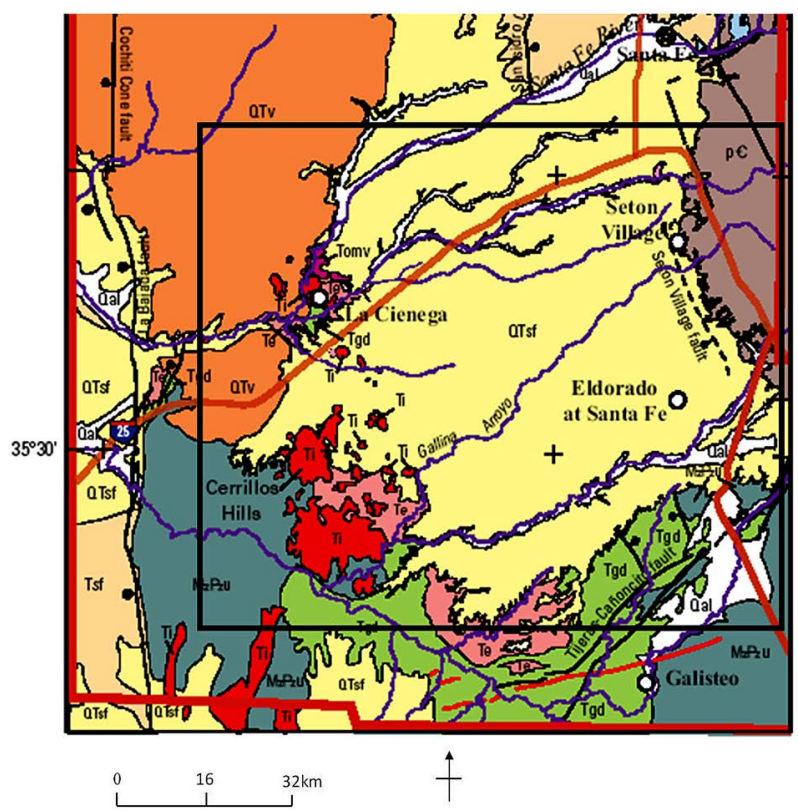

Figure 1. Boundary of the study area with regional structures, volcanic fields, mountain ranges, and sedimentary basins of north-central New Mexico (modified from [3]).

alluvium, sandstone, shale, siltstone, conglomerate, and limestone of various geologic ages [2]. Prominent igneous intrusions in this area are the Ortiz Mountains and Cerrillos Hills as well as numerous local volcanic structures such as dikes, laccoliths, and other igneous geometries throughout the Galisteo Basin.

The results from this research project provided a general insight into the petroleum exploration of other continental rift zones, rifted margins and sedimentary basins in North Central region of the United States such as Cherokee Basin in the state of Wyoming and the Anadarko Basin in the western part of the state of Oklahoma which experienced similar geologic events.

\section{Geologic Setting}

The Galisteo Basin is one of a series of structural depressions composing the Southern Espanola Basin and part of the Rio Grande Rift, which formed during crustal extension from late Oligocene (33.7 Ma to 23.8 Ma ) to present. The Rio Grande Rift is a general north-south alignment of structurally complex basins extending from southern Wyoming to Mexico. The Espanola basin is located in a major right step in the Rio Grande Rift system with a general form of a west-dipping half graben. It adjoins the east-dipping San Luis basin on the northeast and the transitional Santo Domingo and east-dipping Albuquerque Basin in the southwest.

\section{Methods and Data}

Land-based gravity and magnetic data were obtained where accessible, from 56 gravity stations and 250 magnetic stations within the northern-central part of the Galisteo Basin south of Santa Fe, NM. The study area extends south from the village of Eldorado to the foothills of the Ortiz Mountains and east from I-25 to Highway 285, an area of approximately $2200 \mathrm{~km}^{2}$ (Figure 2). These new measurements were along public and private roads and were accessed mainly by car and foot. The gravity-magnetic measurements were established in regional traverses and combined with information from geologic mapping, core and log data, and seismic depth picks [4], to characterize the subsurface. Accurate location of survey stations were achieved using Garmin GPSMAP 60CSx equipment while absolute elevations were collected by means of a Brunton Nomad V2 digital compass.

\subsection{Data Reduction}

The gravity data were corrected for instrumental drift, tides, latitude, and elevation. The final product of all corrections and data reduction is a complete Bouguer anomaly map (Figure 3). The Bouguer anomalies correlate with lateral variation in density of the upper crust and are determined by taking the difference between the observed measurements and the theoretically calculated value (GRS67) for that location and interpreted in terms of subsurface properties.

Magnetic data collected with the Geometrics 856AX proton magnetometer were corrected for diurnal variations and the regional field in much the same way as the gravity data for drift and tidal effects. Having applied these corrections, all remaining variations in magnetic field can be attributed to spatial fluctuations in the induced magnetic properties of the subsurface rocks referred to as magnetic anomalies. Similarly, the final outputs is imported into ArcGIS to produce a magnetic anomaly map (Figure 4(A)).

\subsection{Model Construction}

Analysis of gravity and magnetic data requires the application of mathematical methods to investigate the depth and shape of the anomalies. The techniques employed in this research include gravity and magnetic anomaly separation and depth estimation. Anomaly separation applies enhancement techniques to isolate various long wavelength components and provide a means to assess the relationship between the regional, local, shallow, and deep sources. One such technique is the first derivative that tends to increase the perceptibility of small amplitude anomalies which are easily obscured by the regional gravity field [5].

The first and second vertical derivative methods both enhance near-surface anomalies at the expense of deeper 


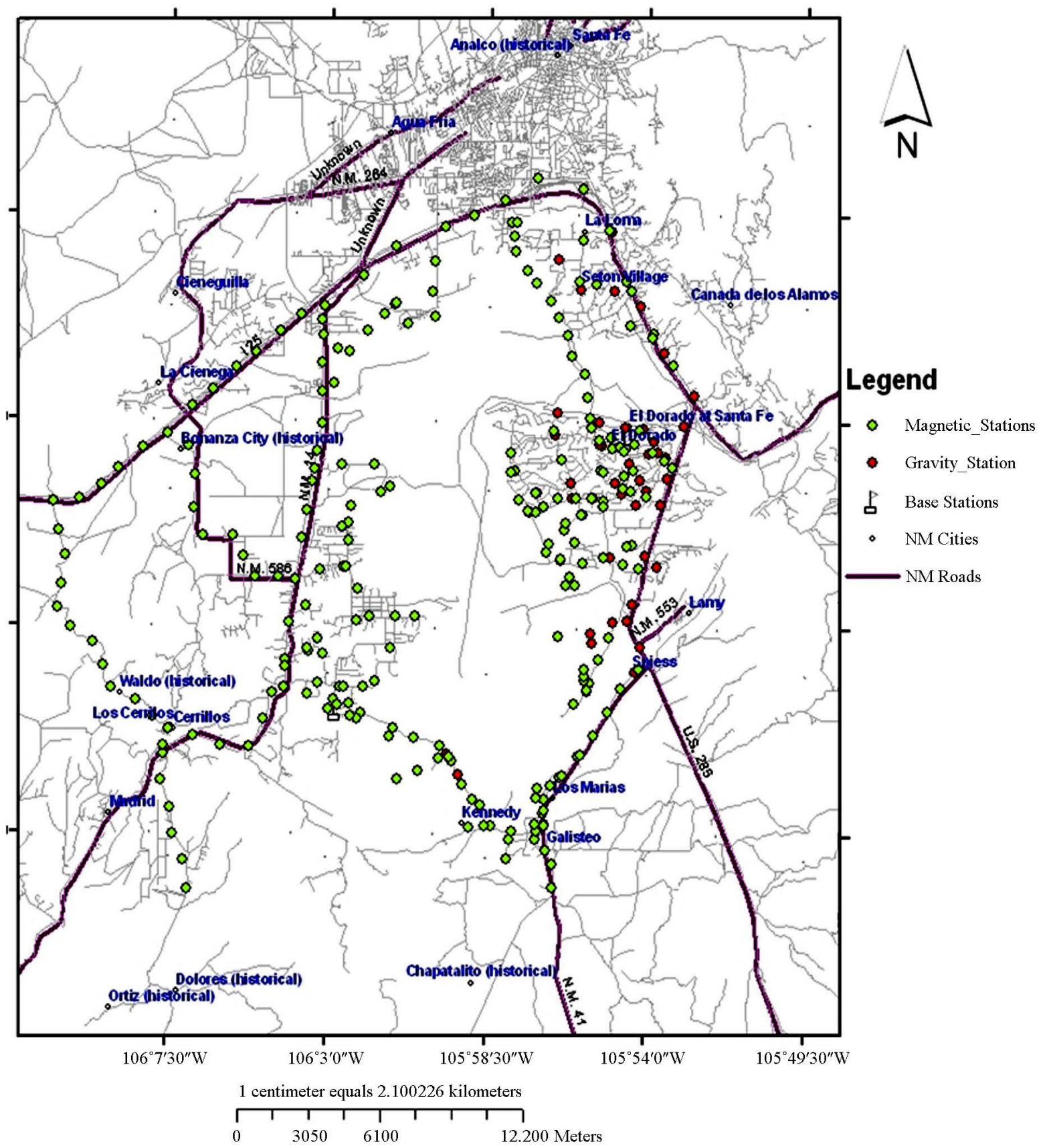

Figure 2. Gravity and magnetic measurement stations established in the Galisteo Basin.

anomalies and are good at locating the edges of a body with subsequent modeling to determine the depth, density, susceptibility contrast and geometry of the anomalous sources. Depth estimation techniques were subsequently used to estimate the depths to the gravity or magnetic sources and were applied to gridded gravity data sets (constructed in Surfer software) along three main profiles across selected anomalies (Figure 4(B)). Within the study area, deep gravity lows are associated commonly with accumulated sediments or volcanic tuffs which are less dense than the surrounding rocks. A density-depth func- tion of the different units within the study area had been defined [3].

\section{Results and Interpretations}

Seismic-reflection data support the northwest-trending gradient of the gravity data shown on Figure 3. This trend is attributed to the fact that a greater volume of lower density pre-rift sedimentary section lies on the southwestern part of the basin, compared with the north. In other words, the pre-rift sedimentary section is much 


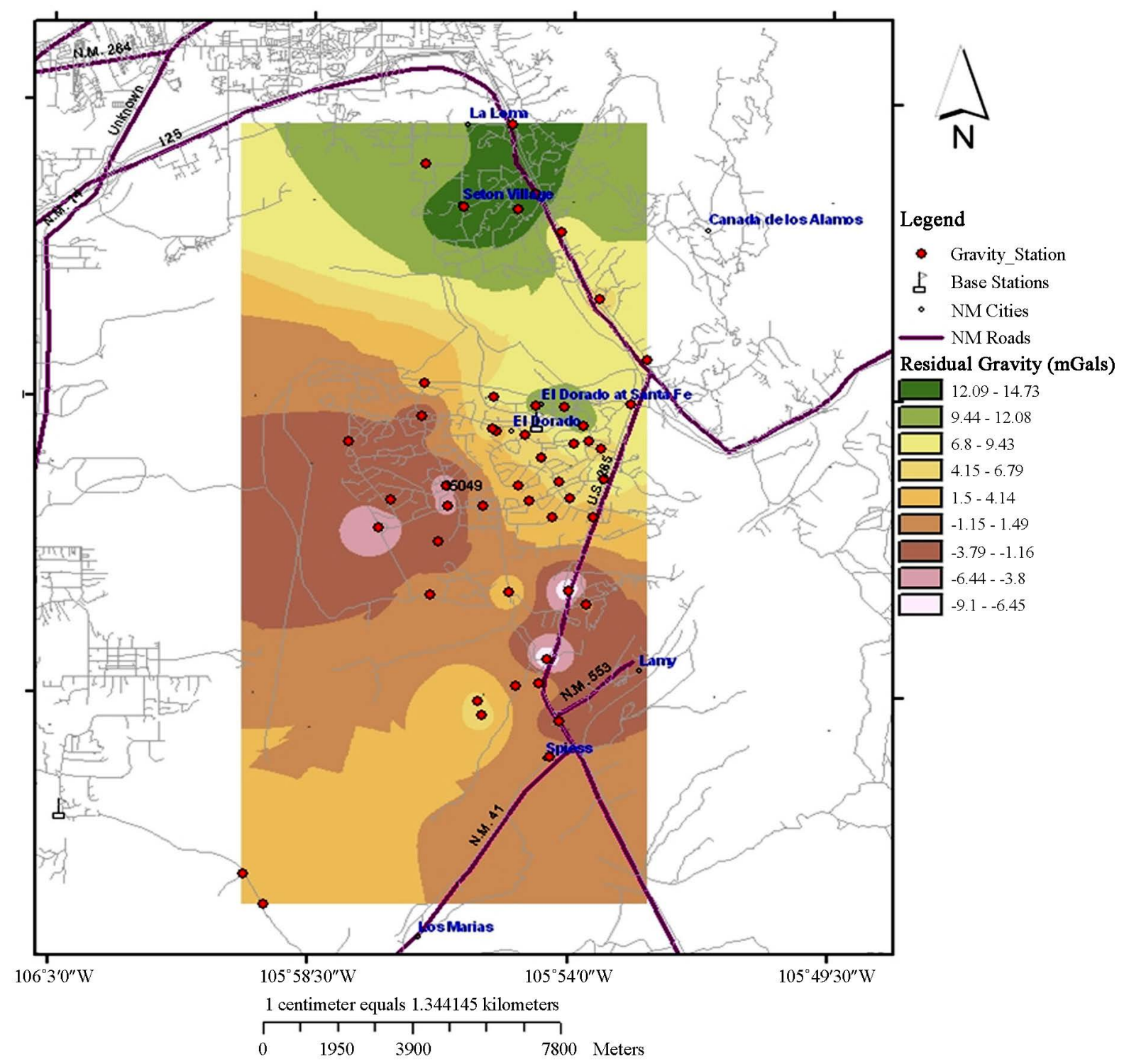

Figure 3. Bouguer anomaly map of the study area with potential target areas for hydrocarbon traps (faults) within the study area.

thinner in the north compared to the southern parts of the Basin. A model of the North-South profile of the gravity data, constrained by the magnetic and related information is presented as Figure 5(A), the Seton village profile as Figure 5(B), and the Eldorado profile as Figure 5(C).

\subsection{Interpreting Elements of the Basin Fill}

The Santa Fe Group (SFG) and the Tertiary younger volcanic rocks comprise the sedimentary and volcanic fill of the Rio Grande rift. These sediments consist of Quaternary (QTv) - Tertiary rift-related volcanic rocks, mainly basalts, that usually do not exceed depths of about 2.5 $\mathrm{km}$ [6]. By using the density-depth function [5], density was modeled between 2.35 to $2.60 \mathrm{~g} / \mathrm{cm}^{3}$. Also, although the SFG consist of several units [7], the basin fill was modeled as a single unit (Figure 5).

\subsection{Interpreting Elements of the Basin Floor}

There are only a few areas of high magnetic signatures on the geomagnetic map (Figure 4(A)). The dominant broad anomaly features on this map are likely associated with Precambrian basement rocks, which include the broad magnetic high around Eldorado at Santa Fe, and the intrusive rocks of the Cerrillos Hills located on the southwestern part of the Galisteo Basin. The small circular anomalies could be induced by anthropogenic factors such as landfills or underground pipes while the moderate magnetic features are linked to pre-rift volcanic and volcaniclastic rocks in the southern part of the Galisteo Basin and linear features related to faulting [3]. 

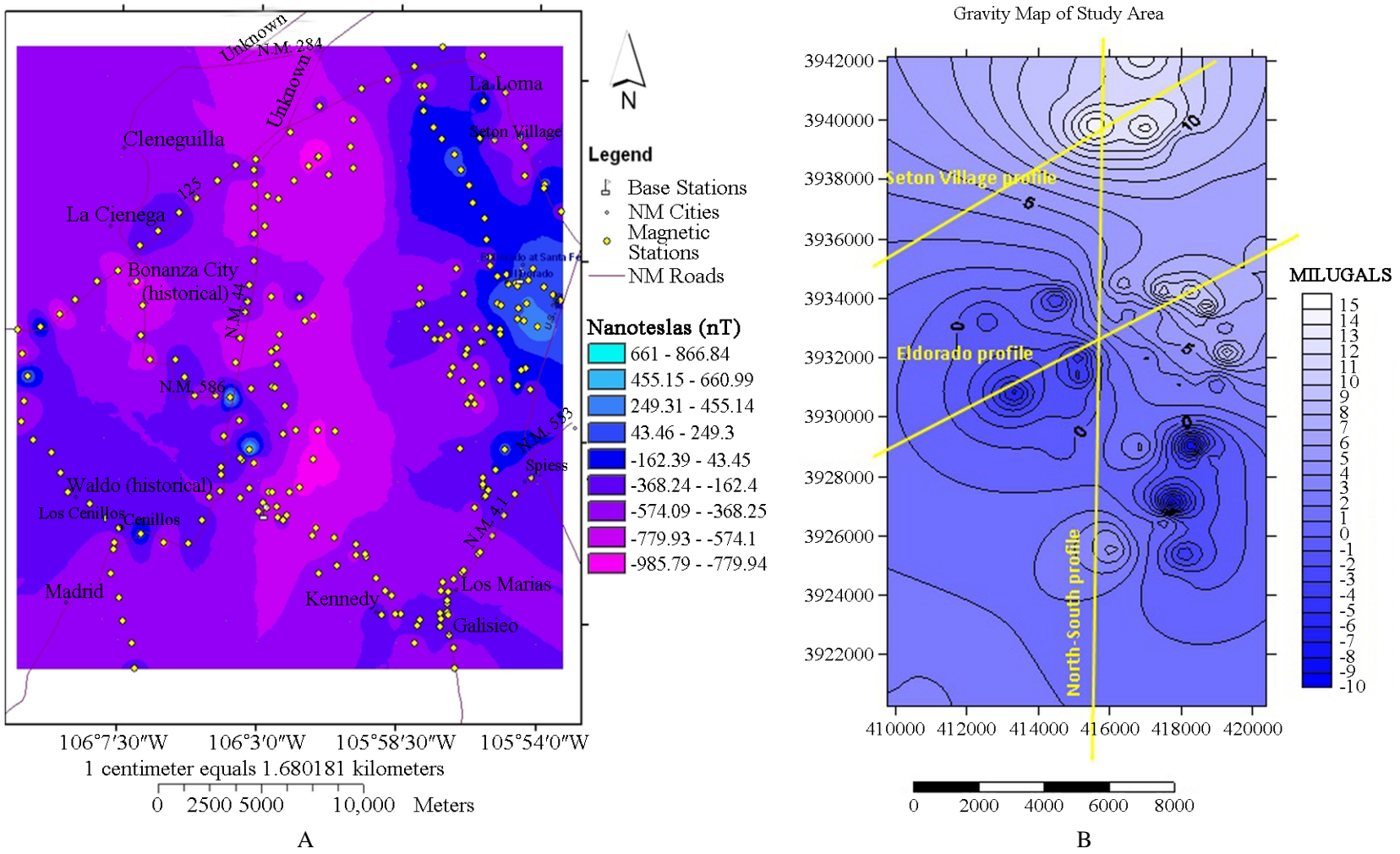

Figure 4. Potential field maps of the study area. (A) Total magnetic field; (B) Bouguer anomaly mapwith selected profiles for depth to anomaly modeling.
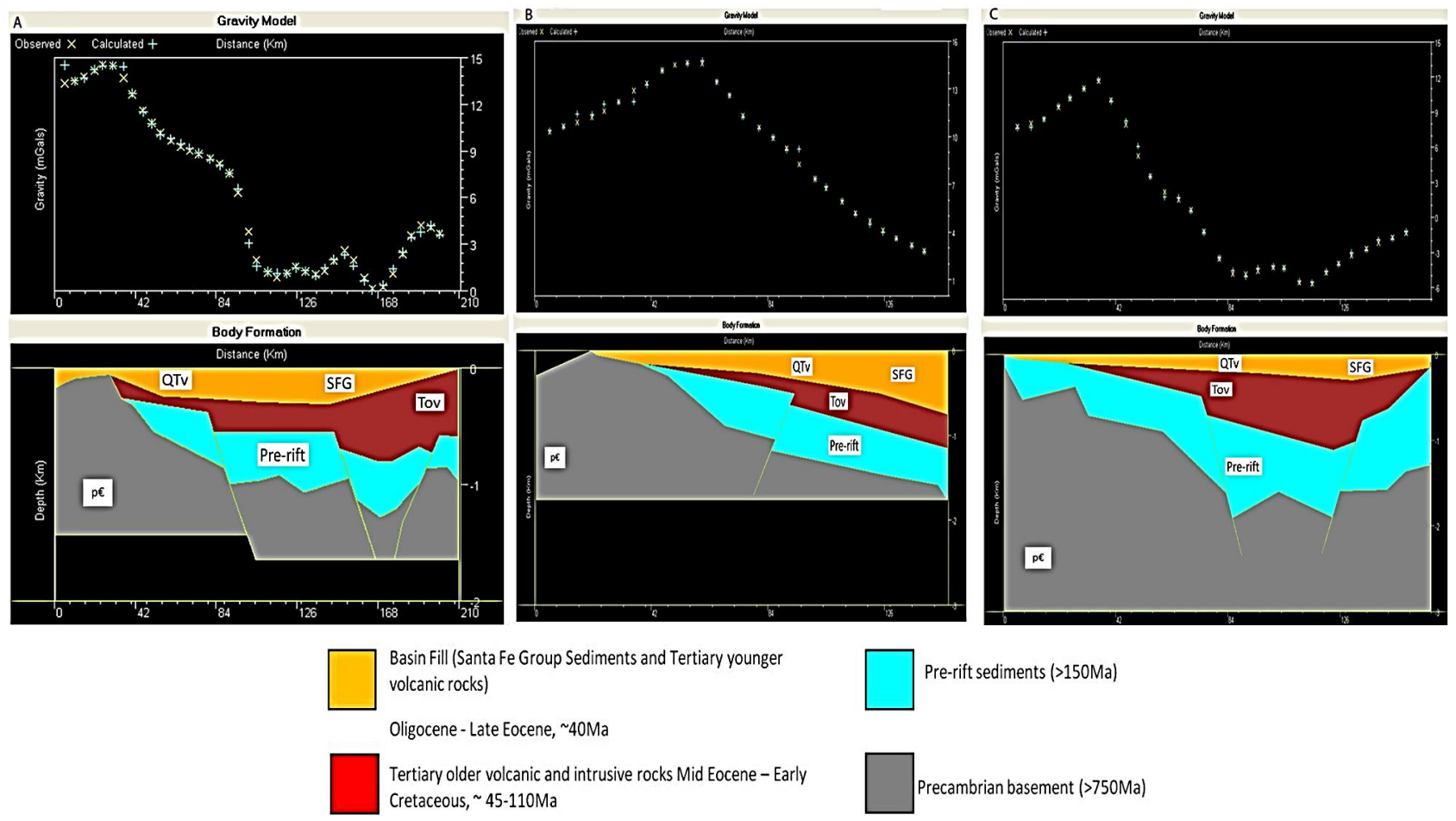

Precambrian basement $(>750 \mathrm{Ma})$

Figure 5. Final geologic models. Models show possible bodies of different densities and shapes offset by several faults, creating a potential for hydrocarbon accumulation. (A) North-South profile, $210 \mathrm{~km}$ south of Seton Village; (B) Seton Village profile, $150 \mathrm{~km}$ NW of Seton Village; (C) Eldorado profile, $160 \mathrm{~km}$ south west of Eldorado Village, with a much thicker pre-rift sediment as compared to the other models. 
The basin geometry is clearly seen in the Bouguer anomaly map, with the highest gravity values representing relatively dense basement areas $(p €)$ that have been uplifted, while the lowest values represent the deepest parts of the basin and consist of mixed, less dense Tertiary older volcanic (Tov) and pre-rift (Pre-rift) volcanic and volcaniclastic sediments. The pre-rift sections of most parts of the Espanola Basin are not more than $3 \mathrm{~km}$ thick [8].

The North-South profile, Seton Village Profile, and the Eldorado profile required massive Precambrian basements with densities between 2.60 to $2.70 \mathrm{~g} / \mathrm{cm}^{3}$. Pre-rift sediments (Paleozoic to Eocene, with densities between 2.52 to $2.59 \mathrm{~g} / \mathrm{cm}^{3}$ ) rest unconformably on the Precambrian basement which may be variably eroded throughout the Galisteo Basin, and intruded by the Cerrillos Hills intrusive complex of similar densities. The Pre-rift sediments are overlain by a less dense body, likely Tertiary older volcanic rocks with densities between 2.42 to 2.48 $\mathrm{g} / \mathrm{cm}^{3}$ and the Santa Fe group sediments.

Hydrocarbon traps likely exist within the Galisteo Basin, and the gravity and magnetic data point towards several areas for further study. Virtually all of the parameters necessary for oil and gas accumulations exist in the $\mathrm{Al}$ buquerque Basin, Santa Fe Embayment, and possibly the Galisteo Basin [9,10]. The Galisteo Basin like many other areas within the Espanola Basin, presents intervening faults (Figure 3), which have acted as avenues for migrating hydrocarbons from potential source rocks at depth, up the faults, into reservoirs located on the highs.

\section{Conclusions}

The basic equations that describe the potential field characteristics or rocks have been used to determine the likely densities and magnetic susceptibilities of subsurface rocks of selected parts of the Galisteo Basin. Data from these reconnaissance surveys were combined with reference information from surface geologic mapping, seismic, and log interpretation to model the gravity data, constrained by the magnetic information in 2 dimensions using the Talwani gravity modeling software. Several possible faulted areas were identified that could also be areas of high structural relief or fold dominated traps such as synclines and anticlines. These intervening normal faults may act as structural trap avenues for migrating hydrocarbons from the potential source area to the reservoir. Excellent reservoirs may also be present within the Cretaceous and Jurassic Formations while lateral changes in stratigraphy might have created interesting opportunities for stratigraphic traps, although these are very difficult to image with gravity and magnetic data alone.

The geophysical maps and models generated in this study only serve as reconnaissance data for more detailed geophysical investigations and to target areas for seismic exploration. It is recommended that station spacing not be greater than $500 \mathrm{~m}$ for future surveys, to better identify small scale anomalies and intrusions. Until closed structural traps are located and drilled the potential of the Rio Grande Rift in general, and the Galisteo Basins in particular, will not be exploited to their full potential.

\section{REFERENCES}

[1] M. Talwani, J. Worzel and M. Landisman, "Rapid Gravity Computations for Two-Dimensional Bodies with Application to the Mendocino Submarine Fracture Zone," Journal of Geophysical Research, Vol. 64, No. 1, 1959, pp. 49-61. http://dx.doi.org/10.1029/JZ064i001p00049

[2] Office of the State Engineer, "Galisteo Basin Hydrology Report,” Office of the State Engineer, Santa Fe, 2008.

[3] V. Grauch, J. D. Phillips, J. D. Koning, J. S. Peggy and V. Bankey, "Geophysical Interpretation of the Spouthern Espanola Basin, New Mexico, that Contribute to Understanding Its Hydrogeologic Framework,” Professional Paper 1761, USGS, Reston, 2009.

[4] D. A. Sawyer and S. A. Minor, "Geologic Setting of the La Bajaga Constriction, New Mexico,” USGS Professional Paper 1720-A, United States Geological Survey, Reston, 2006, pp. 1-2.

[5] Z. J. Fajklewicz, "Gravity Vertical Gradient for the Detection of Small Geologic and Anthropomorphic Forms," Geophysics, Vol. 41, No. 5, 1976, pp. 1016-1030. http://dx.doi.org/10.1190/1.1440657

[6] S. M. Cather, "Suggested Revisions to the Tertiary Tectonic History of North-Central New Mexico," Guidebook 43, New Mexico Geologic Society, Socorro, 1992, pp. 109-122.

[7] D. J. Koning and S. D. Connell, "Stratigraphy and Depositional Trends in the Santa Fe Group near Espanola," Guide Book 56, New Mexico Geologic Society, Socorro, 2005, pp. 237-257.

[8] W. S. Baldridge, G. L. Cole, B. A. Robinson and G. R. Jiracek, "Application of Time-Domain Airborne Electromagnetic Induction Hydrogeologic Investigation on the Pajarito Plateau, New Mexico, USA,” Geophysics, Vol. 72, No. 2, 2001, pp. B31-B45.

[9] B. A. Black, "Hydrocarbon Potential of the Espanola Basin-A Progress Report,” Guidebook 35, New Mexico Geologic Society, Socorro, 1984, pp. 223-226.

[10] L. R. Russell and S. Snelson, "Structural Style and Tectonic Evolution of the Albuquerque Basin Segment of the Rio Grande Rift, New Mexico, USA,” In: M 59: Interior Rift Basins, A.A.P.G. Memoir, Tulsa, 1994, pp. 205-258. 